\title{
MANAJEMEN PERSONALIA SEBAGAI UPAYA DALAM MENINGKATKAN KUALITAS PERSONALIA DI MADRASAH
}

\author{
Oleh: \\ Romdloni \\ Dosen STKIP Nurul Huda OKU Timur \\ romdloni29@gmail.com
}

\begin{abstract}
ABSTRAK
Manajemen adalah suatu proses penataan dengan melibatkan sumbersumber potensial baik yang bersifat manusia maupun yang bersifat non manusia dalam rangka mencri tujuan yang efektif dan efisien. Adapun manajemen personalia adalah manajemen yang menitik beratkan perhatiannya kepada soal-soal pegawai atau personalia di dalam suatu organisasi. Keberhasilan suatu pendidikan tidak hanya dilihat dari manajemen kelas, kurikulum, murid dan sebagainya, tetapi juga manajemen personalia ikut berperan dalam keberhasilan suatu pendidikan. Maka diperlukan manajemen personalia. Manajemen personalia adalah perencanaan, pengorganisasian, pengarahan, dan pengawasan kegiatankegitan, pengadaan, pengembangan dan pemberian kompensasi, pengintegrasian, pemeliharaan dan pelepasan sumberdaya manusia agar tercapai berbagai tujuan individu dan organisasi dalam masyarakat.

Kata kunci: Manajemen, Personalia, Madrasah
\end{abstract}

\section{A. PENDAhUluAN}

Sekolah sebagai pusat pendidikan formal, ia lahir dan berkembang dari pemikiran efisiensi dan efektivitas di dalam penyelenggaraan pendidikan kepada warga masyarakat terutama bagi peserta didik. Sekolah sebagai pusat pendidikan formal merupakan perangkat masyarakat yang diserahi kewajiban pemberian pendidikan. Perangkat ini ditata dan dikelola secara formal mengikuti haluan yang pasti dan diperlukan di masyarakat bersangkutan. Haluan tersebut tercermin didalam falsafah dan tujuan, pengajaran, kurikulum, pengadministrasian serta pengelolaan. ${ }^{1}$

Dalam rangka pencapaian standar sekolah yang berkualitas dan bermutu sesuai dengan tujuan pendidikan dalam sekolah tersebut maka diperlukan adanya dukungan terhadap seluruh komponen pendidikan yang

1 Tim Dosen FIP-IKIP Malang, Pengantar Dasar-Dasar Kependidikan (Surabaya: Usaha Nasional, 1980), hlm. 146 
terpusat dalam suatu sistem yang saling menunjang dalam mencapai keberhasilan pendidikan, seperti yang telah disampaikan oleh Suratman bahwa filsafat, dasar, tujuan, sarana dan prasarana, metode dan kurikulum pendidikan, anak didik dan lingkungan seluruhnya berada dalam satu kaitan yang tidak terpisahkan dan saling menunjang satu sama lain untuk keberhasilan pendidikan. ${ }^{2}$

Manajemen pendidikan merupakan alternatif strategis untuk meningkatkan kualitas pendidikan. Manajemen sekolah/madrasah secara langsung akan mempengaruhi dan menentukan efektif tidaknya kurikulum, berbagai peralatan belajar, waktu mengajar, dan proses pembelajaran.

Manajemen atau pengelolaan merupakan komponen integral dan tidak dapat dipisahkan dari proses pendidikan secara keseluruhan. karena tanpa manajemen tidak mungkin tujuan pendidikan dapat diwujutkan secara optimal, efektif, dan efisien. Penerapan manajemen sekolah/madrasah secara menyeluruh memerlukan perubahan mendasar terhadap aspekaspek yang menyangkut keuangan, ketenagaan, kelas, kurikulum, sarana dan prasarana, serta partisipasi masyarakat dan lain-lain.

Keberhasilan suatu pendidikan tidak hanya dilihat dari manajemen kelas, kurikulum, murid dan sebagainya, tetapi juga manajemen personalia ikut berperan dalam keberhasilan suatu pendidikan. Maka diperlukan manajemen personalia. Manajemen personalia adalah perencanaan, pengorganisasian, pengarahan, dan pengawasan kegiatan-kegitan, pengadaan, pengembangan dan pemberian kompensasi, pengintegrasian, pemeliharaan dan pelepasan sumberdaya manusia agar tercapai berbagai tujuan individu dan organisasi dalam masyarakat. ${ }^{3}$

Pada prinsipnya yang dimaksud personalia disini ialah orang-orang yang melaksanakan sesuatu tugas untuk mencapai tujuan dalam hal ini di sekolah/madrasah dibatasi dengan sebutan pegawai. Oleh karena itu personil di sekolah/madrasah tentu saja meliputi unsur guru yang disebut tenaga edukatif dan unsur karyawan yang disebut tenaga administratife. Secara terperinci dapat disebutkan keseluruhan personil sekolah/madrasah adalah, kepala sekolah/madrasah, guru, pegawai administrasi (TU) dan pesuruh penjaga sekolah/madrasah.

${ }^{2}$ Soeratman, Permasalahan Tentang Kesejahteraan Pendidikan (Jakarta: FIP, 1978), hlm. 15

${ }^{3}$ Flippo, Manajemen Personalia (Jakarta: Erlangga, 1984), hlm. 5

70| Manajemen Personalia Sebagai Upaya Dalam Meningkatkan Kualitas Personalia Di Madrasah 
Di dalam berlangsungnya kegiatan sekolah maka unsur manusia merupakan unsur penting, karena kelancaran jalannya pelaksanaan program sekolah sangat ditentukan oleh manusia-manusia yang menjalankannya. Dan juga bagaimanapun lengkap dan baik fasilitas yang berupa gedung, perlengkapan, alat kerja, metode-metode kerja, dan dukungan masyarakat akan tetapi apabila manusia-manusia yang bertugas menjalankan program sekolah itu kurang berpartisipasi, maka akan sulitlah untuk mencari tujuan pendidikan yang diharapkan. ${ }^{4}$

Kepala sekolah/madrasah wajib mendayagunakan seluruh personil secara efektif dan efisien agar tujuan penyelenggarakan pendidikan di sekolah/madrasah tersebut tercapai secara optimal. Pendayagunaan ini ditempuh dengan jalan memberikan tugas-tugas jabatan sesuai dengan kemampuan dan kewenangan masing-masing individu. Oleh karena itu adanya "job discription" yang jelas sangat diperlukan. ${ }^{5}$

\section{B. PEMBAHASAN}

\section{Pengertian Manajemen Personalia}

Telah sering disinggung bahwa manajemen adalah proses pengendalian usaha kerja sama sejumlah manusia untuk mencapai suatu tujuan. Pengendalian dan yang dikendalikan adalah manusia. Oleh karena itu, faktor manusia di dalam manajemen sebagai proses merupakan faktor yang utama dan pertama. Faktor manusia adalah faktor yang menentukan dalam keseluruhan proses itu, karena manusialah yang harus bekerja sama agar tujuan yang dirumuskannya dapat dicapai secara efektif. Oleh karena itu dalam proses manajemen faktor manusia harus diatur, dikendalikan dan dikembangkan secara efisien pula, guna meningkatkan aktivitasnya dalam mewujudkan kerja yang terarah pada pencapaian tujuan. Kegiatan pengaturan, pengendalian dan pengembangan faktor manusia itu merupakan aktivitas manajemen kepegawaian atau manajemen personalia.

Istilah personalia, personil atau kepegawaian yang mengandung arti keseluruhan orang-orang yang bekerja pada suatu organisasi. Dengan demikian manajemen personalia adalah manajemen yang menitik beratkan perhatiannya kepada soal-soal pegawai atau personalia didalam suatu organisasi.

\footnotetext{
${ }^{4}$ Daryanto, Administrasi Pendidikan (Jakarta: Rineka Cipta, 2001), hlm. 29-30

${ }^{5}$ Suryo Subroto, Dimensi-Dimensi Administrasi Pendidikan Di Sekolah (Jakarta: Bina Aksara, 1988), hlm. 48
} 
Menurut Made Pidarta, personalia ialah semua anggota yang bekerja untuk kepentingan organisasi yaitu untuk mencapai tujuan yang sudah ditentukan. Personalia organisasi pendidikan mencakup para guru, para pegawai, para wakil siswa atau mahasiswa, dan para alumnus, termasuk juga para manajer pendidikan.

Sedangkan menurut Suryo Subroto yang dimaksud personalia atau personil adalah orang-orang yang melaksanakan suatu tugas untuk mencapai tujuan. Dalam hal ini di sekolah dibatasi dengan sebutan pegawai. Oleh karena itu personil sekolah tentu saja meliputi unsur guru yang disebut tenaga edukatif dan unsur karyawan yang disebut tenaga administratif. ${ }^{6}$

Dari beberapa pendapat yang dikemukakan oleh para ahli manajemen tersebut, dapat dirumuskan bahwa manajemen personalia yaitu perencanaan, pengorganisasian, pengarahan, pengawasan kegiatankegiatan dan pengadaan, pengembangan, pemberian kompensasi pengintegrasian dan pemeliharaan, agar tercapai diberbagai tujuan individu, organisasi dan masyarakat.

\section{Fungsi Manajemen Personalia}

Dalam bukunya Edwin B. Flippo fungsi manajemen personalia adalah:

a. Pengadaan tenaga kerja. Fungsi operasional pertama dari manajemen personalia adalah berupa usaha untuk emperoleh jenis dan jumlah yang tepat dari personalia yang diperlukan untuk menyelesaikan sasaran organisasi. Hal-hal yang dilakukan dalam kaitan ini adalah penentuan sumber daya manusia yan diperlukan dan perekrutannya, seleksi dan penempatan.

b. Pengembangan tenaga kerja. Setelah personalia diperoleh, mereka harus dikembangkan sampai pada tingkat tertentu. Pengembangan merupakan peningkatan keterampilan melalui pelatihan yan perlu untuk prestasi kerja yang tepat.

c. Kompensasi (imbalan) tenaga kerja. Fungsi ini dirumuskan sebagai balas jasa yang memadai yang layak kepada personlia untuk sumbangan mereka kepada tujuan organisasi. Struktur kompensasi meliputi, gaji pokok, tunjangan keuarga, tunjangan makan, tunjangan transportasi, tunjangan kehadiran dan tunjangan jabatan.

d. Integrasi (penyatuan) tenaga kerja. Setelah karyawan diperoleh, dikembangkan, dan diberi kompensasi secara layak, maka selanjutnya adalah intregasi. Integrasi merupakan usaha untuk menghasilkan suatu

${ }^{6}$ Suryo Subroto, op.cit., hlm. 48

72| Manajemen Personalia Sebagai Upaya Dalam Meningkatkan Kualitas Personalia Di Madrasah 
kecocokan yang layak atas kepentingan-kepentingan perorangan, masyarakat, dan organisasi.

e. Pemeliharaan tenaga kerja. Jika kita telah melaksanakan fungsi-fungsi di atas dengan baik, maka yang tidak kalah pentingna adalah pemeliharaan pegawai. Pemeliharaan merupakan usaha untuk meningkatkan kemauan dan kemampuan untuk bekerja para pegawai.

f. Pemutusan hubungan kerja. Fungsi terakhir dari manajemen personalia adalah pemutusan hubungan kerja dan mengembalikan para pekerja kepada masyarakat. Sebagian besar karyawan tidak meninggal dunia pada masa kerjanya. Organisasi bertanggung jawab untuk melaksanakan proses pemutusan hubungan kerja sesuai dengan persyaratanpersyaratan yang telah ditentukan, dan menjamin bahwa warga masyarakat yan dikembalikan itu berada dalam keadaan yang sebaik mungkin. ${ }^{7}$

Fungsi personalia di atas dilaksanakan dan dikerjakan oleh manajer atau pimimpin. Manajer memperoleh hasil dari bawahannya, dan agar bawahannya dapat berprestasi besar dan cakap bekerja, maka para pemimpin harus memberi perhatian kepada hal-hal yang berhubungan dengan fungsi personalia.

\section{Prinsip-prinsip Personalia dalam Organisasi}

Menurut Ngalim Purwanto personalia dalam suatu organisasi harus memiliki prinsip-prinsip atau cirri-ciri yaitu:

a. Memiliki tujuan yang jelas.

b. Tiap anggota dapat memahami dan menerima tujuan tersebut.

c. Adanya kesatuan arah sehingga dapat menimbulkan kesatuan tindak dan kesatuan pikiran.

d. Adanya kesatuan perintah.

e. Adanya keseimbangan antara wewenang dan tanggung jawab masingmasing anggota.

f. Adanya pembagian tugas atau pekerjaan sesuai dengan kemampuan, keahlian, dan bakat masing-masing, sehingga dapat menimbulkan kerjasama yang harmonis.

g. Adanya jaminan keamanan dalam bekerja.

h. Adanya gaji yang setimpal dengan jasa atau pekerjaan.

${ }^{7}$ Flippo, op.cit., hlm. 6-7 
i. Garis-garis kekuasaan dan tanggung jawab serta tata kerjanya jelas tergambar dalam struktur organisasi. ${ }^{8}$

Oleh karena itu supaya kegiatan personalia dalam organisasi dapat berjalan lancar, serta personalia dapat bekerja secara efektif maka antara manajer dan bawahan dapat melaksanakan prinsip-prinsip tersebut sesuai dengan jabatan dan kedudukan.

\section{Strategi Pengelolaan Kegiatan yang Mendukung Peningkatan Kualitas Personalia di Madrasah}

\section{a. Pengadaan Personalia atau Pegawai}

Pengadaan pegawai merupakan proses kegiatan untuk mengisi formasi atau tempat serta jabatan yang kosong dan juga pengadaan pegawai dikarenakan adanya perluasan organisasi. Dalam bukunya Slamet Saksono dijelaskan bahwa suatu jabatan atau pekerjaan memerlukan kecakapan (skill), pengetahuan (knowledge) dan kemampuan (ability) tertentu dari yang memangkunya. ${ }^{9}$ Kecakapan, pengetahuan dan kemampuan yang diperlukan ini berbeda antara jabatan atau pekerjaan yang satu dengan yang lainnya. Kecakapan adalah ketrampilan dalam melakukan kegiatan jasmani dan rohani. Kecakapan ini dapat diperoleh melalui latihan atau pengalaman. Pengetahuan menunjukkan bentuk keterangan yang teratur dan berhubungan dengan pelaksanaan pekerjaan yang meliputi prinsip, metode, teknik dan sebagainya. Kemampuan menunjukkan pembawaan dari kecakapan jasmani dan rohani seorang pegawai seperti mengingat-ingat, menalar, mengembangkan dan lain-lain.

Berdasarkan kutipan diatas bahwa dalam pengadaan pegawai diperlukan syarat-syarat yang harus dimiliki oleh pelamar, seperti kecakapan (skill), meliputi kegiatan jasmani dan rohani, kecakapan ini dapat diperoleh melalui latiahan dan pengalaman. Pengetahuan (knowledge) meliputi keterangan-keterangan yang teratu, metode, prinsip, teknik dan sebagainya. Kemampuan (ability) dalam hal ini kaitannya dengan kecakapan jasmani dan rohani yang meliputi mengingat, menalar mengembangkan dan lain-lain.

Di lingkungan lembaga pendidikan khususnya madrasah, tenaga kerja atau pegawai ataupun tenaga pendidik dan tenaga kependidikan dapat dibedakan menjadi dua kelompok, yaitu:

${ }^{8}$ Ngalim Purwanto, Administrasi dan Supervisi Pendidikan (Bandung: Remaja Rosdakarya, 1991), hlm. 17-18

9 Slamet Saksono, Administrasi Kepegawaian (Yogyakarta: Kanisius, 1993), hlm. 50

74| Manajemen Personalia Sebagai Upaya Dalam Meningkatkan Kualitas Personalia Di Madrasah 
Tenaga teknisi atau tenaga profesional atau tenaga edukatif/guru/dosen/pengajar, yakni personal pelaksana proses belajar mengajar dan kegiatan kependidikan lainnya.

2) Tenaga administratif atau tenaga non edukatif/non guru/ non dosen, yakni personal yang tidak langsung bertugas mewujudkan proses belajar mengajar, antara lain meliputi pegawai TU, pegawai laboratorium, keuangan, sopir, pesuruh, jaga malam, pegawai perpustakaan dan lain-lain. ${ }^{10}$

Untuk memelihara efektivitas kerja, pada saat penerimaan dan penempatan pegawai harus diperhatikan persyaratan tuntutan jenis sifat pekerjaan, ketrampilan, pengetahuan dan pengalaman pegawai. Untuk itu dilingkungan setiap lembaga pendidikan diperlukan kegiatan analisis pekerjaan (job analysis) untuk menyusun deskripsi pekerjaan (job description) dan klasifikasi pekerjaan (job classification), agar pada saat penerimaan dan penempatan pegawai dapat disesuaikan antara pegawai yang diperlukan dengan tuntutan jenis dan sifat pekerjaan.

Dalam rangka pengadaan personil atau rekrut personil terutama guru, banyak cara yang dapat dipakai, yaitu:

1) Spoils systems, yaitu sistem pengadaan personil yang didasarkan pada kesamaan kepartaian, dalam arti pengisian pekerjaan atau jabatan yang ada di usahakan teman separtai, tanpa atau kurang memperhatikan apakah kandidat memenuhi kualifikasi atau tidak.

2) Nepotism systems yaitu cara mengadakan personil yang di dasarkan pada hubungan kekeluargaan.

3) Menit systems yakni cara pengadaan personil berdasarkan kecakapan yang dimiliki.

4) Career systems yakni cara pengadaan personil yang pada awalnya didasarkan pada kecakapan sedang pada proses lanjut, selain kecakapan pada masa kerja, loyalitas dan syarat kerja lainnya turut mendukung.

5) Sistem prestasi, cara ini terutama berlaku bagi personil lama yang hendak naik pangkat atau hendak menduduki jabatan yang lebih tinggi. Kenaikan pangkat di dasarkan pada kecakapan dan prestasi kerja yang dimiliki. Kecakapan dibuktikan dengan lulus ujian sedang prestasi dibuktikan dengan melalui karya nyata. ${ }^{11}$

${ }^{10}$ Hadari Nawawi, Administrasi Pendidikan (Jakarta: Gunung Agung, 1984), hlm. 65-66

${ }^{11}$ Harbangab Siagian, op.cit. . 
Jadi dari pembahasan diatas bahwa penerimaan dan penempatan pegawai harus memperhatikan kualifikasi para individu dari pegawai tersebut. Dalam penerimaan dan penempatan pegawai yang tidak tepat, menimbulkan berbagai kerugian dan masalah karena setiap pekerjaan yang dilimpahkan tidak akan terselesaikan secara efektif, dengan demikian tenaga dan waktu akan terbuang-buang, bahkan mungkin pula menjadi pemborosan karena biaya dipergunakan untuk personel yang tidak mampu mencapai prestasi seperti yang diharapkan.

\section{b. Pengembangan Personalia}

Pengembangan personalia ialah tata cara atau peninjauan kembali untuk menjamin stabilitas kepegawaian. Perkembangan personal merupakan salah satu kegiatan penting bagi kemajuan sekolah/madrasah.

Keberhasilan program pengembangan personal, di dalam beberapa hal banyak dipengaruhi oleh peranan pimpinannya. Mereka diperlukan mulai dari tahap perencanaan, pelaksanaan dan penyelesaian pogram itu. Walaupun pimpinan sudah memberikan kesempatan baik dalam menyediakan fasilitas secukupnya, itu semua belum cukup masih ada yang diperlukan dari dia, yaitu kemauan, keseriusan dan kesungguhan di dalam melaksanakan. Dengan singkat dapat dikatakan bahwa manajemen pimpinan merupakan kunci untuk program pengembangan personal ini. ${ }^{12}$

Sebab-sebab dilaksanakannya pengembangan personalia, yaitu; 1) adanya tata cara atau peraturan baru dalam personalia tersebut, 2) adanya pegawai yang kurang cakap, 3) adanya mesin-mesin baru, dan 4) perlunya penyegaran kembali khususnya pegawai. ${ }^{13}$ Sedangkan tata cara peningkatan mutu karyawan dapat dilakuan dengan diadakan suatu latihan dan pendidikan. Latihan adalah suatu kegiatan atau usaha untuk meningkatkan pengetahuan dan ketrampilan seorang pegawai dalam melaksanakan tugas atau pekerjaan tertentu.

Menurut Instruksi Presiden No 15 tahun 1974, latihan adalah bagian pendidikan yang menyangkut poses belajar unuk memperoleh dan meningkatkan ketrampilan di luar sistem pendidikan yang berlaku dalam waktu yang relatif singkat dan dengan metode yang lebih mengutamakan praktik daripada teori.

12 Suharsimi Arikunto, Organisasi Administrasi Pendidikan Teknologi Dan Kejuruan (Jakarta: Rajawali Pers, 1990), hlm. 134

${ }^{13}$ Hendayat Soetopo dan Wasty Soemanto, Pengantar Operasional Administrasi Pendidikan (Surabaya: Usaha Nasional, 1982), hlm. 169

76| Manajemen Personalia Sebagai Upaya Dalam Meningkatkan Kualitas Personalia Di Madrasah 
Latihan yang dilakukan oleh personalia atau pegawai bertujuan agar pegawai bekerja lebih efisien. Selain itu, latihan ini juga dilakukan agar pegawai dapat mengembangkan keahliannya, sehingga pekerjaan apat diselesaikan dengan lebih cepat dan efisien, serta mengembangkan sikap dan pengetahuan pegawai.

Latihan dan pendidikan dapat diberikan dengan cara: 1) dengan penjelasan dan contoh-contoh kerja dan training, 2) dengan sistem individual atau klasikal, 3) dengan rapat, 4) lokakarya (penjelasan dan pameran), dan 5) briefing (penjelasan yang bersifat instruksi).

Pembinaan dan pengembanan terhadap staf tidak hanya pada nggota yang baru saja, tetapi juga kepada seluruh staf. Pembinaan harus dilakukan secara terus menerus dan secara sistematis. Pembinaan ini sangat penting karena perkembangan baik perkembangan ilmu pengetahuan, perkembangan teknologi, maupun perkembangan masyarakat dan kebijaksanaan-kebijaksanaan yang baru.

Jadi dalam rangka meningkatkan efisiensi kerja, masalah pembinaan pegawai menempati kedudukan yang penting. Program pembinaan pegawai meliputi aspek yang cukup luas antara lain mengenai peningkatan kemampuan kerjanya, peningkatan dedikasi, moral dan disiplin kerja serta pengarahan dan pembentukan motif kerja yang obyektif. Peningkatan kemampuan dan kemahiran kerja dapat ditempuh dengan jalan menambah pengetahuan dan latihan-latihan bagi para personal melalui penataran, tugas belajar, latihan kerja di lingkungan sendiri atau lingkungan lain dan di dalam maupun di luar negeri. Program peningkatan kerja harus diarahkan untuk, memungkinkan tenaga kerja yang tersedia dipergunakan secara berdaya guna dan berhasil guna, menciptakan hubungan kerja yang menyenangkan dan produktif dalam rangka mencapai tujuan, dan meningkatkan perkembangan tenaga kerja sampai batas kemampuan maksimal masingmasing dan sesuai pula dengan perkembangan cara dan peralatan kerja yang terbaru dan terbaik.

\section{c. Hubungan Antarpersonalia}

Menurut Hoy hubungan antarpersonalia berkaitan dengan iklim organisasi. Iklim organisasi ialah karakteristik organisasi tertentu yang membedakannya dengan organisasi yang lain yang dapat mempengaruhi perilaku anggotanya. ${ }^{14}$

Produktivitas pendidikan ditentukan oleh praktik dan tradisi atau kebiasaan bekerja personalianya. Bila para personalia memiliki kebiasaan

${ }^{14}$ Made Pidarta, Iop.cit., hlm. 134 
bekerja secara efektif dan efisien akan dapat meningkatkan produktivitas, sebaliknya bila mereka memiliki kebiasaan secara santai dan kurang cermat akan dapat merugikan organisasi. Dengan demikian iklim organisasi perlu dibina dan ditingkatkan.

Memperhatikan dan membina organisasi berarti sekaligus menjunjung martabat para personalia sebagai manusia, sebab dengan memperbaiki iklim organisasi akan mengembangkan sikap-sikap sosial, toleransi, menghargai pendapat orang lain, bekerja sama menyelesaikan masalah, dan sebagainya. Semua perilaku adalah cermin cara bekerja sama yang baik. Bila perilaku ini dapat di pertahankan relatif lama, maka ia akan menjadi tradisi atau kebiasaan bekerja. Lalu terciptalah iklim organisasi yang baik.

Hubungan antarpersonalia yang diinginkan dalam lembaga pendidikan ialah, kerukunan, gotongroyong, saling menghormati, kerjasama dan rasa saling memiliki. Dalam hubungan tersebut dilakukan oleh semua personalia tanpa terkecuali, terutama manajer memberi contoh sikap-sikap yang baik.

Halsey memberikan petunjuk tentang bagaimana seharusnya atasan bertindak terhadap para bawahan agar mereka menyukaidan menyenangi atasannya. Petunjuk-petunjuk itu adalah:

1) Harus bersikap adil.

2) Mereka harus disalami segera ketika bertemu.

3) Mereka perlu diberi perhatian.

4) Atasan lebih banyak mendengar daripada berbicara.

5) Atasan sebaiknya memakai kata meminta bukan memerintah.

6) Nama-nama para bawahan perlu diingat dan disebutkan bila berhubungan dengan mereka. ${ }^{15}$

Cara lain yang dapat dilakukan oleh para manajer adalah menciptakan situasi yang harmonis, gotongroyong, saling menghargai, mengutamakan kepentingan bersama, membela kebenaran dan keadilan, dan sikap musyawarah dalam setiap pertemuan. Penciptaan situasi-situasi tersebut merupakan teknik pembinaan antar hubungan secara tidak langsung kepada setiap personalia pendidikan.

\section{d. Pemeliharaan Personalia}

Maksud dari pemeliharaan personalia atau ketenagaan adalah usahausaha untuk menjamin terpenuhinya secara optimal kebutuhan sosial ekonomi maupun sosial psikologis para pegawai. Yang termasuk dalam berbagai usaha pemenuhan kebutuhan tersebut di atas antara lain:

${ }^{15}$ Ibid., hlm. 138

78| Manajemen Personalia Sebagai Upaya Dalam Meningkatkan Kualitas Personalia Di Madrasah 
1) Gaji. Untuk Pegawai Negeri Sipil peraturan gaji yang berlaku sekarang ialah berdasarkan Peraturan Pemerintah No. 15 tahun 1985, yaitu tentang Peraturan Gaji Pegawai Negeri Sipil.

2) Tunjangan kesejahteraan.

3) Pemeliharaan kesehatan maupun keselamatan fisik dan mental pegawai.

4) Perlakuan yang adil dan wajar.

5) Penghargaan terhadap setiap prestasi.

6) Perwujudan semangat kekeluargaan, persaudaraan dan kerjasama. ${ }^{16}$

Jadi ada dua macam kesejahteraan yang perlu diperhatikan dan diusahakan oleh pimpinan sekolah/madrasah, yaitu yang menyangkut kesejahteraan material dan kesejahteraan batin. Kesejahteraan material menyangkut pemenuhan kebutuhan hidup, yaitu gaji yang cukup, fasilitas perumahan, dana, kesehatan, pensiun, dan sebagainya. Kesejahteraan batin meliputi perasaan aman, perasaan diakui atau diterima, perasaan diperlakukan adil, perasaan berprestasi, perasaan dianggap pentin, perasaan berpartisipasi, perasaan memperoleh harga diri dari pekerjaannya dan sebagainya.

\section{e. Kesejahteraan Personalia}

Untuk meningkatkan kegairahan bekerja dan menjamin hari tua diselenggarakan usaha peningkatan kesejahteraan pegawai. Peningkatan kesejahteraan tersebut harus diusahakan secara bertahap sesuai dengan kemampuan sehingga pada akhirnya pegawai dapat memusatkan perhatian sepenuhnya untuk melaksanakan tugasnya.

Secara konsep, meningkatkan kesejahteraan para anggota organisasi memang merupakan salah satu tugas manajer. Organisasi adalah merupakan salah satu bentuk kehidupan bersama dengan tujuan tertentu yang sudah disepakati bersama. Untuk mencapai tujuan itu, para manajer perlu mengarahkan, membina, dan mengkoordinasi anggota-anggotanya, salah satu media penting dalam mengarahkan mereka, agar hati mereka lebih mudah brgerak untuk maju adalah kesejahteraan.

Mengenai kesejahteraan personalia diuraikan oleh David Barber bahwa manajemen yang baik memberikan keamanan, kesehatan dan memberikan lingkungan kerja yang enak kepada semua karyawan atau pegawaimanajer personalia. Harus juga mempertimbangkan kondisi kerja seperti masalah jam kerja, liburan, tunjangan untuk pegawai seperti tunjangan sakit, pensiun dan lain-lain. $^{17}$

\footnotetext{
${ }^{16}$ Piet A. Sahertian, Ibid., hlm. 168

${ }^{17}$ David Barber, Manajemen Personalia (Jakarta: Erlangga, 1982), hlm. 71-72
} 
Uraian di atas sangat jelas sekali bahwa kesejahteraan personalia merupakan bagian dari manajemen yang harus benar-benar diperhatikan oleh manajer, tanpa membedakan antar individu.

Menurut Piet A. Sahertian, yang termasuk dalam berbagai usaha pemenuhan kebutuhan personalia meliputi gaji, tunjangan kesejahteraan, pemeliharaan kesehatan maupun keselamatan fisik dan mental pegawai, perlakuan adil dan wajar, penghargaan setiap prestasi, perwujudan semangat kekeluargaan, persaudaraan dan kerja sama. ${ }^{18}$

Banyak cara dan usaha yang dapat dilakukan kepala sekolah/madrasah dalam rangka meningkatkan kesejahtearan personel sekolah/madrasah. Di samping pemberian insentif dan atau gaji yang layak, usaha meningkatkan kesejahteraan personel dapat pula dilakukan dengan jalan; 1) membentuk semacam ikatan keluarga sekolah yang bersifat social, 2) membentuk koperasi keluarga personel sekolah/madrasah, dan 3) mengadakan kegiatankegiatan seperti olah raga, diskusi-diskusi yang berhubungan dengan pengembangan profesi guru-guru atau pegawai sekolah, 4) memberi kesempatan dan bantuan dalam rangka pengembangan karier, seperti kesempatan melanjutkan pelajaran, kesempatan mengikuti penataranpenataran, selama tindakan mengganggu atau merugikan jalannya sekolah/madrasah, dan 5) mengusulkan dan mengurus kenaikan gaji atau pangkat guru-guru dan pegawai tepat pada waktunya sesuai dengan peraturan yang berlaku. ${ }^{19}$

Semua yang telah dibicarakan di atas memerlukan adanya kepemimpinan kepala sekolah/madrasah yang baik dan bijaksana disertai pengawasan dan pembinaan yang tepat dan berkelanjutan.

\section{f. Penilaian Personalia}

Dalam penilaian pegawai meliputi pencatatan mengenai segala kegiatan kepegawaian untuk megetahui karya-karya yang dicapai oleh seorang pegawai. Satu istilah lain yang sering di gunakan dalm penilaian pegawai ialah merit rating, yang berarti pencatatan jasa-jasa atau prestasi-prestasi pegawai. Merit rating dipakai dalam penilaian pegawai berdasarkan sistem karir.

${ }^{18}$ Piet A. Sehertian, Op.Cit

${ }^{19}$ Ngalim Purwanto, op.cit.

80| Manajemen Personalia Sebagai Upaya Dalam Meningkatkan Kualitas Personalia Di Madrasah 
Yang dimaksud penilaian ketenagaan ialah usaha-usaha yang dilakukan untuk mengetahui secara formal maupun informal untuk mengetahui hal-hal yang menyangkut pribadi, status, pekerjaan, prestasi kerja maupun perkembangan pegawai sehingga dapat dikembangkan pertimbangan nilai obyektif dalam mengambil tindakan terhadap seorang tenaga.

Beberapa hal yang penting untuk dinilai oleh kepala sekolah/madrasah adalah; 1) kemampuan kerja (perencanaan program mengajar, kecakapan mengajar, melaksanakan administrasi), 2) kerajinan, 3) kepatuhan disiplin kerja, 4) rasa tanggung jawab terhadap tugas-tugasnya, 5) hubungan kerja sama, 6) kelakuan di dalam dan di luar dinas, 7) prakarsa (inisiatif), 8) kepemimpinan, dan 9) pekerjaan pada umumnya.

Dalam pelaksanaannya penilaian terhadap pegawai dapat dilakukan oleh atasan langsung dan oleh atasan tidak langsung. Yang dimaksud atasan langsung ialah atasan yang mempunyai wewenang secara langsung untuk memberikan perintah kepada seorang bawahan. Bawahan langsung ialah seorang bawahan yang secara langsung bertanggung jawab kepada seorang atasan tanpa melalui pejabat lain. Atasan mengetahui secara langsung perkembangan bawahannnya. Oleh karena itu penilaian yang dilakukan oleh atasan langsung diharapkan akan lebih obyektif.

Adapun atasan tidak langsung ialah atasan yang dalam memberikan suatu perintah kepada salah seorang bawahan tidak dapat secara langsung, melainkan melalui jalur yang telah ditetapkan dalam struktur organisasi. Bawahan tidak langsung ialah bawahan yang dalam memberikan suatu pertanggungjawaban tidak dapat secara langsung, melainkan melalui jalur yang telah ditetapkan dalam organisasi. ${ }^{20}$

Terlepas dari apakah suatu penilaian dilakukan oleh atasan langsunag atau oleh atasan tidak langsung, hasil penilaian harus ditunjukkan kepada pegawai yang bersangkutan. Hal ini bertujuan agar pegawai yang bersangkutan berkesempatan untuk mengajukan keberatan-keberatan apabila ia menganggap penilaian itu tidak obyektif.

Penilaian pegawai perlu dilakukan karena penilaian pegawai memiliki manfaat ganda, yaitu bagi pegawai dan perusahaan atau sekolah/madrasah. Manfaat penilaian pegawai bagi pegawai antara lain; 1) penilaian pegawai menciptakan iklim kehidupan perusahaan, yang dapat menjamin kepastian hukum bagi pegawai, 2) penilaian pegawai memberikan dorongan kepada pegawai untuk lebih giat dalam melaksanakan tugas dan pekerjaannya, dan

${ }^{20}$ Wursanto, Manajemen Kepegawaian I (Surabaya: Kanisius, 2003), hlm. 89 
3) penilaian pegawai melatih pegawai untuk selalu berdisiplin dalam segala hal, baik ketika pimpinan hadir maupun tidak hadir.

Sedangkan manfaat penilaian pegawai bagi perusahaan atau lembaga pendidikan antara lain; 1) rapat mengetahui kelemahan-kelemahan yang dialami oleh setiap pegawai sehingga pembinaan pegawai dapat lebih dikembangkan dan diperhatikan, 2) hasil penilaian dapat dipergunakan sebagai dasar untuk menempatkan pegawai sesuai dengan bidang dan tugasnya, dan 3) penilaian pegawai memudahkan dalam menentukan apakah suatu latihan dibutuhkan untuk mengembangkan keterampilan pegawai. Jadi penilaian terhadap personalia itu meliputi semua aspek kepribadian yang berhubungan dengan tugas-tugasnya selama bekerja di sekolah/madrasah itu.

Penilaian prestasi yang dilakukan oleh kepala sekolah atau manajer merupakan salah satu bagian tugas yang penting untuk dilakukan. Walaupun demikian, melakukan penilaian prestasi seseorang secara obyektif bukanlah merupakan suatu pekerjaan yang sederhana, karena penilaian prestasi perseorangan merupakan langkah utama menilai efektifitas organisasi. Dan dengan penilaian tersebut dapat mengakibatkan kejadian yang tidak menyenangkan, baik bagi penilai maupun bagi yang dinilai.

Menurut Adam bahwa penilaian prestasi memberikan informasi yang dapat digunakan untuk membuat tentang promosi dan kenaikan gaji. Selanjutnya dengan penilaian prestasi memberikan kesempatan kepada pimpinan dan orang yang dinilai untuk secara bersama-sama membahas perilaku kerja dari yang dinilai. Kemudian dengan penilaian prestasi juga memungkinkan penilai dan yang dinilai untuk secara bersama-sama menemukan dan membahas penyimpangan-pemyimpangan yang terjadi dan mengambil langkah perbaikannya. ${ }^{21}$

Dari uraian di atas dapat dijelaskan bahwa penilaian prestasi itu memiliki tiga fungsi yang bermanfaat bagi penilai, bagi yang dinilai dan bagi kemajuan kelembagaan. Fungsi dari penilaian prestasi adalah untuk membuat keputusan tentang promosi dan kenaikan gaji, untuk memberikan kesempatan kepada pemimpinan dan bawahan dalam membahas perilaku kerja yang dinilai dan untuk secara bersama membahas atau memberikan solusi dari penyimpangan-penyimpangan yang terjadi.

${ }^{21}$ Adam I. Indrawijaya, Perilaku Organisasi (Bandung: Sinar Baru, 1989), hlm. 215

82| Manajemen Personalia Sebagai Upaya Dalam Meningkatkan Kualitas Personalia Di Madrasah 


\section{PENUTUP}

Personalia atau personil adalah orang-orang yang melaksanakan suatu tugas untuk mencapai tujuan. Dalam hal ini di sekolah/madrasah dibatasi dengan sebutan pegawai. Oleh karena itu personil sekolah/madrasah tentu saja meliputi unsur guru yang disebut tenaga edukatif dan unsur karyawan yang disebut tenaga administratif. Dari beberapa pendapat yang dikemukakan oleh para ahli manajemen tersebut, dapat dirumuskan bahwa manajemen personalia yaitu perencanaan, pengorganisasian, pengarahan, pengawasan kegiatan-kegiatan dan pengadaan, pengembangan, pemberian kompensasi pengintegrasian dan pemeliharaan, agar tercapai diberbagai tujuan individu, organisasi dan masyarakat.

Bukan hanya para personalia saja yang perlu dibina atau dikembangkan melainkan juga madrasahnya perlu dibina dan dikembangkan. Tujuan pengembangan baik melalui personalia maupun melalui organisasi ialah memperbaiki performance organisasi dengan menciptakan iklim sumber daya manusia yang positif. Agar proses pengembangan para personalia madrasah berjalan lancar dan kontinu, maka perlu dan dibutuhkan kepemimpinan yang efektif. Yaitu suatu kepemimpinan yang menghargai usaha para bawahan, yang memperlakukan mereka sesuai dengan bakat, kemampuan dan minat masing-masing individu, yang memberikan dorongan dan mengarahkan diri ke arah tercapainya tujuan lembaga pendidikan Islam. Dan kepemimpinan yang efektif selalu memanfaatkan kerjasama dengan para bawahan untuk mencapai cita-cita organisasi.

\section{DAFTAR RUJUKAN}

Arikunto, Suharsimi. 1990. Organisasi Administrasi Pendidikan Teknologi dan Kejuruan. Jakarta: Rajawali Pers.

Armstrong, Michael. 1990. A Handbook of Human Resources Management. Alih bahasa oleh Sofyan Cikmat dan Haryanto dengan judul Manajemen Sumber Daya Manusia. Jakarta: Elex Media Komputindo

Barber, David. 1982. Manajemen Personalia. Jakarta: Erlangga.

Daryanto. 2001. Administrasi Pendidikan. Jakarta: Rineka Cipta.

Flippo, Edwin B. 1984. Manajemen Personalia. Jakarta: Erlangga.

Indrawijaya, Adam I. 1989. Perilaku Organisasi. Bandung: Sinar Baru.

L. Daft, Richard. 1986. Organization Theory and Desaign. New York: West Publishing Company. 
Nawawi, Hadari. 1984. Administrasi Pendidikan. Jakarta: Gunung Agung.

Pidarta, Made. 2004. Manajemen Pendidikan Manusia. Jakarta: PT. Rineka Cipta.

Purwanto, Ngalim. 1991. Administrasi dan Supervisi Pendidikan. Bandung: Remaja Rosdakarya.

Saksono, Slamet. 1993. Administrasi Kepegawaian. Yogyakarta: Kanisius.

Soeratman. 1978. Permasalahan Tentang Kesejahteraan Pendidikan. Jakarta: FIP.

Soetopo, Hendayat dan Wasty Soemanto. 1982. Pengantar Operasional Administrasi Pendidikan. Surabaya: Usaha Nasional.

Subroto, Suryo. 1988. Dimensi-Dimensi Administrasi Pendidikan di Sekolah. Jakarta: Bina Aksara.

Sudirman. 1991. Ilmu Pendidikan:Kurikulum, Program pengajaran, Efek Intruksional dan pengiring, CBSA, Metode mengajar, Media pendidikan, Pengelolaan kelas dan Evaluasi hasil belajar. Bandung: Remaja Rosdakarya.

Sudjana, Nana. 1989. CBSA Dalam Proses Belajar Mengajar. Bandung: Sinar Baru.

Sugiyono. 2005. Memahami Penelitian Kualitatif. Bandung: CV. Alfabeta.

Sukardi. 2003. Metodologi Penelitian Pendidikan:Kompetensi dan Praktiknya. Jakarta: PT. Bumi Aksara.

Sutisna, Oteng. 1979. Supervisi dan Administrasi Pendidikan. Bandung: Jenmars.

Syafaruddin. 2002. Manajemen Mutu Terpadu Dalam Pendidikan, Konsep Strategi dan Aplikasi. Jakarta: Grasindo.

Tim Dosen FIP-IKIP Malang. 1980. Pengantar Dasar-Dasar Kependidikan. Surabaya: Usaha Nasional.

Usman, Mohammad Uzer. 1995. Menjadi Guru Profesional. Bandung: PT. Remaja Rosdakarya Offset.

Wursanto. 2003. Manajemen Kepegawaian I. Surabaya: Kanisius.

84| Manajemen Personalia Sebagai Upaya Dalam Meningkatkan Kualitas Personalia Di Madrasah 